\title{
The Use of Exhaust Gas Recirculation for Ensuring the Environmental Performance of Marine Diesel Engines
}

\section{Recirkulacija ispušnih plinova s cijeljem skrbi za okoliš tijekom rada brodskih dizelskih motora}

\author{
Sergii Victorovych Sagin \\ National University Odessa Maritime \\ Academy \\ Ukraine \\ e-mail: saginsergii@gmail.com
}

\author{
Oleksiy Andriiovych Kuropyatnyk \\ Graduate Student \\ National University Odessa Maritime Academy" \\ Ukraine \\ e-mail: kuropyatnyk83@gmail.com
}

\author{
DOI 10.17818/NM/2018/2.3 \\ UDK 621.43 .058 \\ 629.5:621.4 \\ Preliminary communication / Prethodno priopćenje \\ Paper accepted / Rukopis primljen: 26. 1. 2018.
}

\begin{abstract}
Summary
The article deals with the operational features of internal combustion engines of marine vessels during their operation in special environmental areas - Nitrogen Oxide Emission Control Areas. According to the requirements of Annex VI MARPOL, during the operation of marine diesel engines in these areas the content of nitrogen oxides in the exhaust gases should be less than $3.4 \mathrm{~g} /(\mathrm{kW} \times \mathrm{h})$. The article touches upon the possible technical measures to ensure the maintenance of the required level of nitrogen oxide emissions in the exhaust gases of marine diesel engines. The authors propose to use an exhaust gas recirculation system, with a certain amount of gases supplied back to the cylinder after preliminary cooling and mixing with air, which reduces the maximum combustion temperature to values that prevent the formation of nitrogen oxides. The experiment proved that the recirculation of exhaust gases in the $4.7 . . .18 .8 \%$ range helps to reduce the concentration of nitrogen oxides in exhaust gases by 19.5 ... $48.8 \%$. At the same time, it is necessary to ensure values that meet the requirements of international organizations aimed at protecting the air from pollution and allowing the use of marine vessels in areas of increased environmental control.
\end{abstract}

\begin{abstract}
Sažetak
Članak se bavi operativnim značajkama brodskih motora s unutarnjim izgaranjem u posebnim područjima zaštite okoliša - područja kontrole emisija dušikovih oksida. Prema odredbama Priloga VI. MARPOL konvencije, tijekom rada brodskih dizelskih motora, $u$ posebnim područjima sadržaj dušikovih oksida u ispušnim plinovima ne smije prelaziti 3,4 g/(kWXh). Članak se bavi potencijalnim tehničkim mjerama za održavanje određene razine emisija dušikovih oksida u ispušnim plinovima brodskih dizelskih motora. Autori predlažu uporabu sustava recirkulacije ispušnih plinova s određenom količinom plinova koji se vraćaju u cilindar nakon prethodnog hlađenja i miješanja sa zrakom, što smanjuje najvišu temperaturu izgaranja do vrijednosti koje sprječavaju stvaranje dušikovih oksida. Pokus je potvrdio da recirkulacija ispušnih plinova u rasponu od 4,7 do $18,8 \%$ pomaže pri smanjenju koncentracije dušikovih oksida u ispušnim plinovima za 19,5 do 48,8 \%. istodobno je potrebno osigurati vrijednosti koje su u skladu s propisima međunarodnih organizacija s ciljem zaštite zraka od onečišćenja i uporabe brodskih motora u područjima povećane kontrole okoliša.
\end{abstract}

\section{KEY WORDS}

low-speed marine diesel

environmental performance of a diesel engine concentration of nitrogen oxides in exhaust gases exhaust gas recirculation effective power specific fuel oil consumption

\section{INTRODUCTION / Uvod}

In addition to generating useful energy that is transferred to the propeller and ensures the movement of the vessel, internal combustion engines can pollute the surrounding sea and air environment in various ways. Oil residues (contaminated fuel and oil, whose dispersed state does not allow the fuel equipment to inject them into the combustion chamber) and exhaust gases directly emitted into the atmosphere belong to the list of the main products that adversely affect the environment as a result of the operation of any thermal engine [Sagin, Solodovnikov, 2015]. Oil residues (waste of fuel, oil separation and filtration, as well as inseparable emulsions of water and fuel) are collected in special tanks and subsequently handed over to shorebased recycling and utilization stations [Petzold et al., 2011]. Unfortunately, the exhaust gases are emitted directly into the atmosphere and become subject to additional purification only in single cases [Rakhmatov, 2014]. In this regard, a number of international organizations (in particular, the International Maritime Organization - IMO) establish strict requirements, the implementation of which allows ensuring the environmental performance of marine diesel engines [Balzani et al., 2014].

At present, there are strict standards for individual components contained in the exhaust gases of internal 

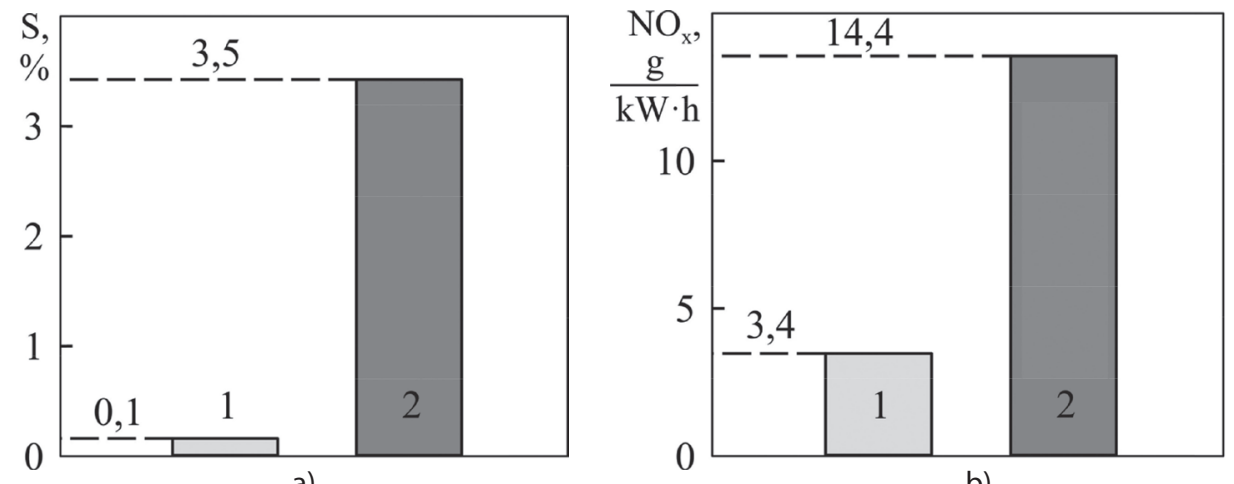

Figure 1 The requirements of international organizations for the sulphur content in fuel (a) and the content of emissions of nitrogen oxides in exhaust gases (b): 1 - when the marine vessel is in special ecological areas, namely Sulfur Emission Control Areas (SECAs) and Nitrogen Oxide Emission Control Areas (NECAs); 2 - when the marine vessel is outside of special ecological areas.

Slika 1. Zahtjevi međunarodnih organizacija za sadržaj sumpora u gorivu (a) i za sadržaj emisija dušikovih oksida u ispušnim plinovima (b): 1 - kada je plovilo u posebnim ekološkim područjima, tj. u kontrolnim područjima emisije sumpora (SECA) i u kontrolnim područjima emisije dušikovih oksida (NECA); 2 - kada je plovilo izvan posebnih ekoloških područja

combustion engines, such as carbon monoxide $\mathrm{CO}$, hydrocarbons $\mathrm{CH}$, sulphur oxides $\mathrm{SOx}$ and nitrogen oxides NOx. IMO not only introduced standards for the maintenance of SOx and NOx exhaust gases but also defined special marine areas (control zones of SOx and NOx), where the requirements for these parameters are even more regulated.

One of the conditions that ensure the required SOx content in exhaust gases is the use of fuel with a low sulphur content. In accordance with the requirement of Annex VI MARPOL 73/78 from 2012, the permissible sulphur content in fuel used in marine and river vessels should not exceed 3.5\%. According to the requirements of this Convention, from January 1, 2015, in the control areas of gaseous emissions (Emission Control Areas), which include the Baltic Sea, Northern Europe, North America, the coast of California, the Caribbean, the Mediterranean, the coast of Japan, and a number of other territories, the fuel used by marine power plants should not contain more than $0.1 \%$ sulfur (Figure 1, a). According to IMO requirements, from January 1, 2011, the maximum NOx value in exhaust gases is $14.4 \mathrm{~g} /(\mathrm{kW} \times \mathrm{h})$. From January 1, 2016, for all newly built vessels operating in areas where NOx emissions are monitored, this parameter should not exceed $3.4 \mathrm{~g} /(\mathrm{kW} \times \mathrm{h})$ (Figure 1, b).

Despite the development of thermal engines operating by natural gas [Miller Jothi et al., 2008] or biodiesel [Kumar Rajesh \& Saravanan, 2016], the majority of marine vessels use liquid fuels for movement [Sagin \& Semenov, 2016], so the task of reducing the concentration of harmful emissions in exhaust gases generated during combustion will be relevant at least for the next decade.

In this regard, the main goal of this research was to determine the dynamics of the reduction of $\mathrm{NO}_{x}$ emission in the exhaust gases of low-speed marine engines, depending on the degree of their recirculation.

\section{LITERATURE REVIEW / Pregled literature}

The methods for reducing the concentration of $\mathrm{NO}_{x}$ in exhaust gases are divided into two groups: primary and secondary. The primary methods include measures of optimizing the process of fuel formation, fuel supply and combustion, as well as improving the design of fuel equipment. The secondary methods (selective or non-selective catalytic reduction) imply the purification of exhaust gases that are already formed before their release into the atmosphere in additionally installed special facilities (reactors).

The effectiveness of the selective catalytic reduction method (SCR) that is used to purify exhaust gases from NOx can reach 90 ... 95\%. When applying this method, a reagent - generally ammonia or urea - is injected into the exhaust gas flow, then the mixture enters the catalyst [Koci et al., 2008]. Titanium oxide with vanadium, molybdenum or tungsten additives, zeolites, as well as iron oxides with a thin film of iron phosphates or activated carbon in the form of agglomerated granules is used as catalysts [Nova et al., 2008; Hodjati, 2000].

Figure 2 explains the principle of the SCR system operation.

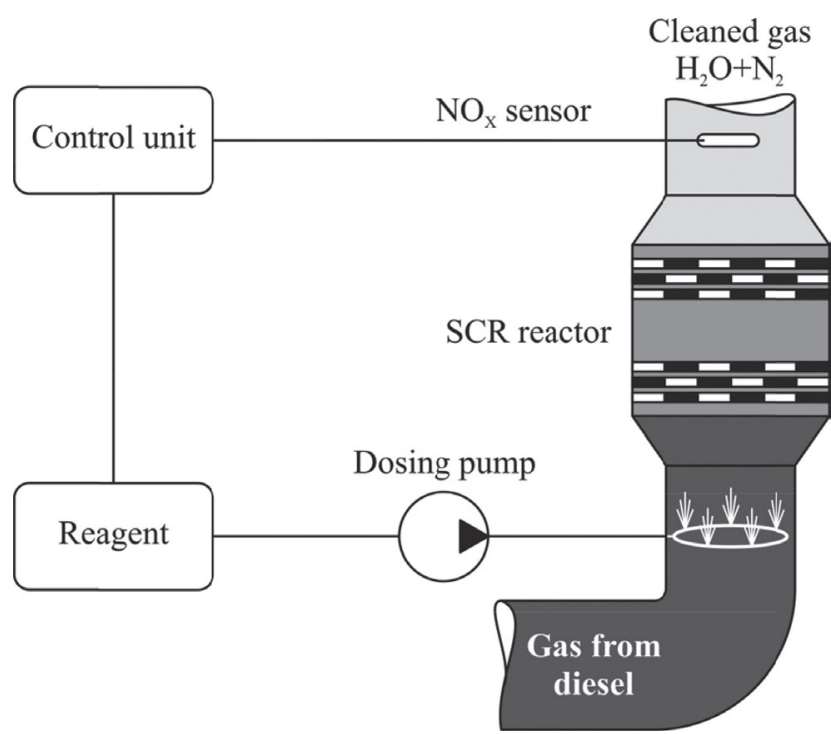

Figure 2 Scheme of the SCR System for Purifying Exhaust Gases from NOx Impurities

Slika 2. Shema SCR sustava za pročišćavanje ispušnih plinova od nečistoća dušikovih oksida

Currently, SCR systems are effectively used in road transport [Yoo et al., 2016]. The application of the SCR system for the purification of the exhaust gases of marine diesel engines is of a one-time nature and is restricted by the high cost of the 
reactor. In addition, the large mass parameters of the reactor and the need for its installation above the engine change the metacentric height of the vessel, which can be critical in conditions of sea disturbance.

The process of fuel combustion in the cylinder of the engine is preceded by the formation of a mixture of finely dispersed particles of fuel and oxygen contained in the air. At the same time (like in any variant of diffusion combustion when fuel and oxidant enter the combustion chamber separately from each other), the stoichiometric ratio is maintained by means of air supply and fuel injection systems. In this case, the emergence of high-temperature foci is inevitable, which, in turn, can lead to the formation of NO. Water or steam that is injected into the combustion system is used as a cooling component to dilute the mixture of fuel and air in the combustion zone. The injection of water into the cylinder can be carried out either through a separate injector or through a common water-fuel injector. Depending on the sequence of water and fuel injection, the injection can be two-phase or multi-phase (Figure 3).

In case of two-phase injection (Figure 3, a), the injector ensures the injection of fuel and water through separate groups of nozzles. The fuel feed pump 1 supplies fuel to the high-pressure fuel pump 2, from which fuel is injected into the injector nozzle. In case of additional injection of fresh water into the diesel cylinder, the sinking pump 6 takes water out the tank 5 and delivers it to the high-pressure pump 7. The amount of fresh water supplied to the cylinder, as well as synchronization of water and fuel injection, is carried out with the help of the controller 4. Given that the diesel operates not only in twophase injection modes but also in modes, in which the diesel works only by fuel, the number of fuel nozzles should remain unchanged and should provide the required cyclic supply of fuel for any diesel load. This creates a need for complementing the injector nozzle with an additional number of nozzles that ensure the injection of fresh air into the cylinder, which complicates the design of the fuel equipment.
In case of multi-phase injection (Figure 3, b), fuel and fresh water are injected into the cylinder through common nozzles. This simplifies the design of the injector (as there is no need for nozzles for different liquids, such as fuel and water), but increases the duration of the cyclic feed (due to the fact that a larger volume of liquid must be supplied through the unchanged cross-section of the injector). Besides, there is a need to increase the fuel injection advance angle, which, in turn, reduces the temperature in the cylinder at the time of injection and can lead to unstable self-ignition of the fuel. In case of multi-phase injection, fuel, water, and the mixture of both alternately enter the cylinder, and their sequencing is regulated by the injection controllers of fuel 3 and water 4 (Figure 3, b). One of the drawbacks of this method is that fuel and water enter the injector nozzle at different temperatures, which affects its temperature stress [Zablotsky et al., 2016].

According to different assessments, the above-described method ensures a $20 . .40 \%$ reduction in the concentration of $\mathrm{NO}_{x}$ in exhaust gases. However, it is necessary to point out that this method is mostly used for reducing the unburnt hydrocarbons and carbon monoxide [Li et al., 2010].

Air humidification can have a similar effect on reducing the temperature of the fuel-air mixture and the subsequent reduction in temperature in the combustion zone. In this case, fresh water is injected into the airflow that is fed to the purge tank and is intended for fuel combustion [Belousov et al., 2010]. In this case, the injectors that spray fresh water can be located both behind the compressor (Figure 4, a) and directly in the blowdown receiver (Figure 4, b). The first variant is known as Combustion air saturation system (CASS), while the second one received the name Humid air motor (HAM).

In the first case, the fresh water supply pump 8 takes water out of the tank 9 and feeds it to the nozzle 7 installed in the airline behind the turbocharger 3 . The air is cooled in the refrigerator 4 and enters the blowdown receiver 6 passing through the additionally installed dehumidifier 5 (which

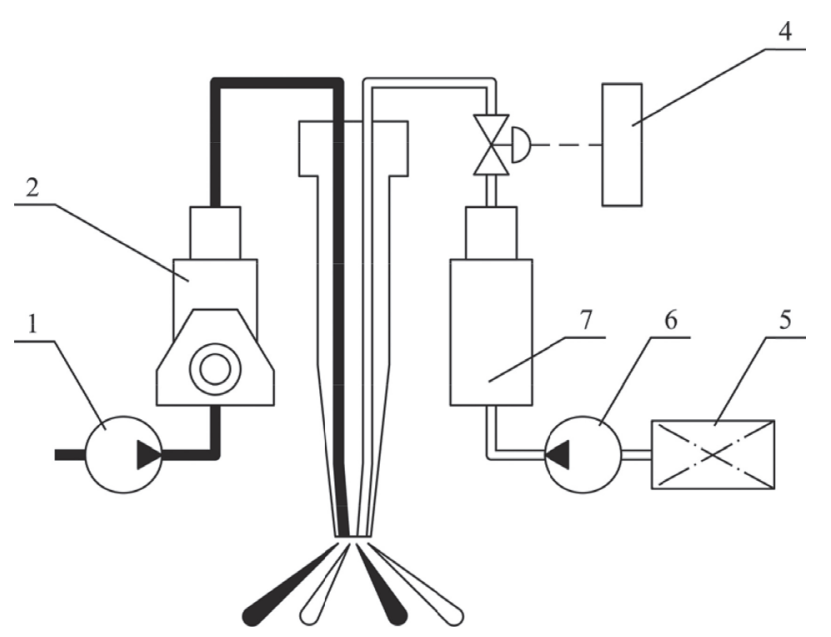

a)

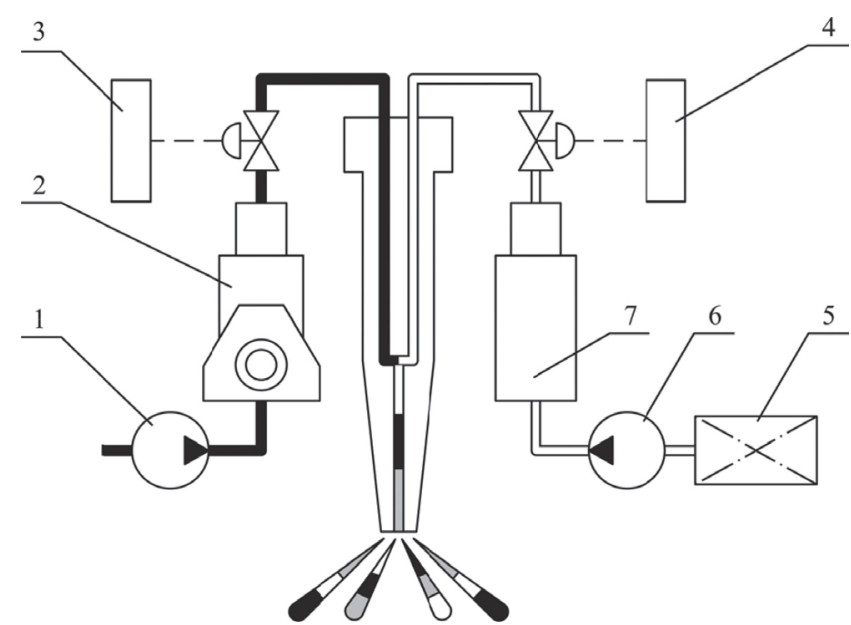

b)

Figure 3 Two-Phase (a) and Multi-Phase (b) Injection:

1 - fuel boost pump; 2 - high-pressure fuel pump; 3 - controller for fuel supply; 4 - controller for water supply; 5 - fresh water tank; 6 - fresh water pump; 7 - high-pressure pump for fresh water

Slika 3. Dvofazno (a) i višefazno (b) ubrizgavanje:

1 - pumpa za povećanje goriva; 2 - visokotlačna pumpa za gorivo; 3 - regulator opskrbe gorivom; 4 - regulator opskrbe vodom; 5 spremnik sa slatkom vodom; 6 - pumpa za svježu vodu; 7 - visokotlačna pumpa za slatku vodu 

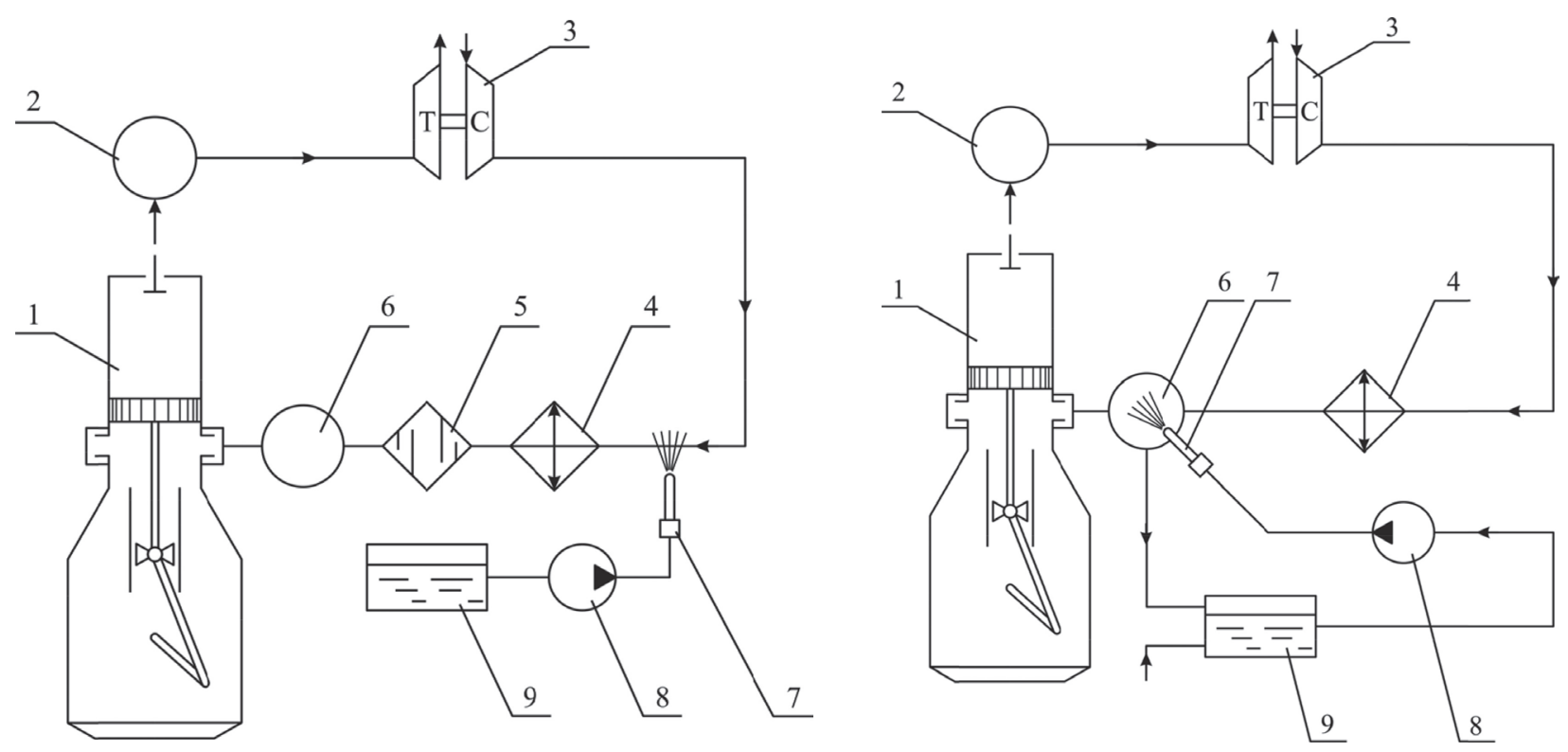

Figure 4 Technological Schemes for Reducing the Concentration of $\mathrm{NO}_{x}$ in Exhaust Gases by Charge Air Humidification: 1 - diesel cylinder; 2 - exhaust manifold; 3 - turbocharger; 4 - charge-air cooler; 5 - dehumidifier; 6 - blowdown receiver; 7 water injection nozzle; 8 - fresh water supply pump; 9 - fresh water tank

Slika 4. Tehnološke sheme ovlaživača zraka za smanjenje koncentracije dušikovih oksida u ispušnim plinovima

1 - dizelski cilindar; 2 - ispušni razvodnik; 3 - turbo punjač; 4 - isparivač; 5 -odvlaživač; 6 - kolektor ispirnog zraka; 7 - mlaznica za ubrizgavanje vode; 8 - pumpa slatke vode; 9 -spremnik slatke vode

ensures the condensation of large water drops).

When using the HAM (Figure 6, b), the nozzle 7 injects fresh water directly into the blowdown receiver 6 . If condensate is formed in the blowdown receiver 6 , it enters the tank 9 , from which it is taken out by the pump 8 and fed to the nozzle 7 .

The use of the above-described methods allows reducing the $\mathrm{NO}_{x}$ concentration in exhaust gases of marine diesel engines to $30-40 \%$. However, it is necessary to point out that these methods can lead to unstable fuel combustion [Zheng et al., 2009]. As it is known, fuel is injected into the cylinder of the diesel engine at some advance angle (at the moment when the piston is not yet at the top dead center), which reduces the temperature at the end of compression in a real cycle as compared to a similar value for an ideal (theoretical) cycle. The availability of an increased portion of sprayed water in the diesel cylinder (which takes place when applying the abovementioned methods for reducing the temperature of the fuelair mixture and increasing the charge air humidification) can lead to a critical decrease in temperature in the diesel cylinder and the impossibility of subsequent self-ignition of the fuel. The injection of water vapour or the supply of additional humidified air into the reaction zone is associated with the complication of the design of both the diesel engine itself and the systems supplying it (compressed air and exhaust gases).

At present, the combustion products that are taken from the exhaust gas flow are used as a diluent of the air-fuel mixture. This method is a system of Exhaust gas recirculation (EGR). The EGR method was initially developed and implemented in road transport. It was used for low-power gasoline engines [Xu et al., 2010; Stein \& Soklakov, 2015], as well as for aircraft diesel engines [Gureev et al., 2016]. At present, it is actively used in marine power plants. Structurally, the EGR system is implemented with the help of an external flue that connects the exhaust manifold and blowdown receiver. Passing through the recirculation system, the combustion products are cooled [Vanin \& Shcheglov, 2014]. This provides only a minimal increase in the specific volume of the fresh air mixture injected by the air compressor, and in the combustion products that enter the recirculation system. The effect of mixing fresh air and exhaust gases (combustion products with a low temperature) can be viewed as diluting the fresh mixture with an inert gas mainly consisting of carbon dioxide $\mathrm{CO}_{2}$ and water vapour $\mathrm{H}_{2} \mathrm{O}$. These products have a high heat capacity and effectively take the heat out of the reaction zone thus reducing its temperature [Zhao et al., 2016]. As a consequence, the concentration of nitrogen oxides NOx in the exhaust gases decreases. The thermal mechanism of the formation of nitrogen oxides is prevalent in the conditions of internal combustion engines [Gusakov et al., 2008].

The energy efficiency of a diesel engine equipped with an EGR system is reduced to a lesser degree as compared with cases when air or water vapour is supplied from the outside, which is due to the fact that the energy of the combustion products partially returns to the system [Manieniyan et al., 2016]. The design of the facility itself (in comparison with the systems of supply and humidification) is simplified since there is no need to create separate units that provide the supply of external components.

\section{MATERIALS AND METHODS / Materijali i metode}

During the last decade, exhaust gas recirculation systems have been increasingly used in marine power engineering for reducing the toxicity of exhaust gases (mainly for reducing the concentration of nitrogen oxides $\mathrm{NO}_{x}$ in the exhaust gases of marine diesel engines). Both main marine engines that transmit power directly to the propeller and powerful auxiliary engines that provide power to the marine power plant (the latter is widely used for cruise ships with large passenger capacity that often sails to coastal waters and areas of environmental control) are 
equipped with the above-described systems [Ajayi et al., 2007].

Mathematical modelling of gas exchange and combustion processes using the EGR system involves the need to take into account the complex phenomena of heat and mass transfer [Kotman et al., 2010]. At the same time, the results obtained do not take into account either the technical state of the diesel engine and its fuel facilities or the EGR system. Therefore, it is recommended to improve the ERG systems and select the most optimal modes of operation based on experimental data obtained directly during the operation of EGR systems that are already installed on internal combustion engines of marine vessels. This kind of studies makes it possible to determine the coordination level of the EGR system and the diesel engine it is installed on, as well as to develop recommendations for its improvement and the selection of the most optimal modes for the operation of the complex of the EGR system and the marine diesel engine.

Taking this into account, the fulfilment of the established goals was carried out through experimental studies aimed at determining the effect of the recirculation degree of exhaust gases on environmental, energy, and economic performance of the internal combustion engine. The object of the research was the gas-discharge system of the 7UEC60LS low-speed marine diesel engine from Mitsubishi operating in a push-pull cycle and equipped with a regular ERG system.

The main characteristics of the diesel engine are as follows:

bore - $600 \mathrm{~mm}$;

piston stroke - $2.400 \mathrm{~mm}$;

number of cylinders- 7;

rated power - $12.600 \mathrm{~kW}$;

rotational speed depending on rated power $-82 \mathrm{rpm}$.

The schematic diagram of the Mitsubishi 7UEC60LS diesel engine with an exhaust gas recirculation system is shown in Figure 5.

From the cylinder of the diesel engine 3 , the exhaust gases enter the exhaust manifold 4 and then to the gas turbocharger 7. Afterwards, they are vented into the atmosphere through the gas outlet pipe. The gas turbocharger 7 takes the air out of the engine room and, after compression directs it through the cooler 1 and receiver 2 to the purging windows of the diesel engine. The exhaust gas recirculation system consists of a control valve 6 , a gas scrubber 5 , a supercharger 10 , a water tank 9 and a water pump 8. Upon the use of an exhaust gas recirculation system, the quantity is controlled by the valve 6 . The exhaust gases are cleared and pre-cooled in the scrubber 5 , after which they pass through the additional supercharger, mix with air (coming through the gas turbocharger 7) and enter the cooler 1 and the receiver 2 , and further into the cylinder of the diesel engine 3 through the purging windows. The gas supercharger 10 was a ventilator with a constant geometry of the flow section. This type of supercharger is widely used in EGR systems of marine vessels. Experimental studies of EGR systems with variable-geometry turbochargers are underway [Lee et al., 2014].

During the experiments, changes in the NOx concentration in exhaust gases, Specific fuel oil consumption (SFOC), and effective diesel power Ne were determined for different degrees of exhaust gas recirculation.

The value of the effective power of the diesel engine $N_{e}$ was determined by indexing the diesel engine with the help of Doctor, a marine diagnostic system for the working process,

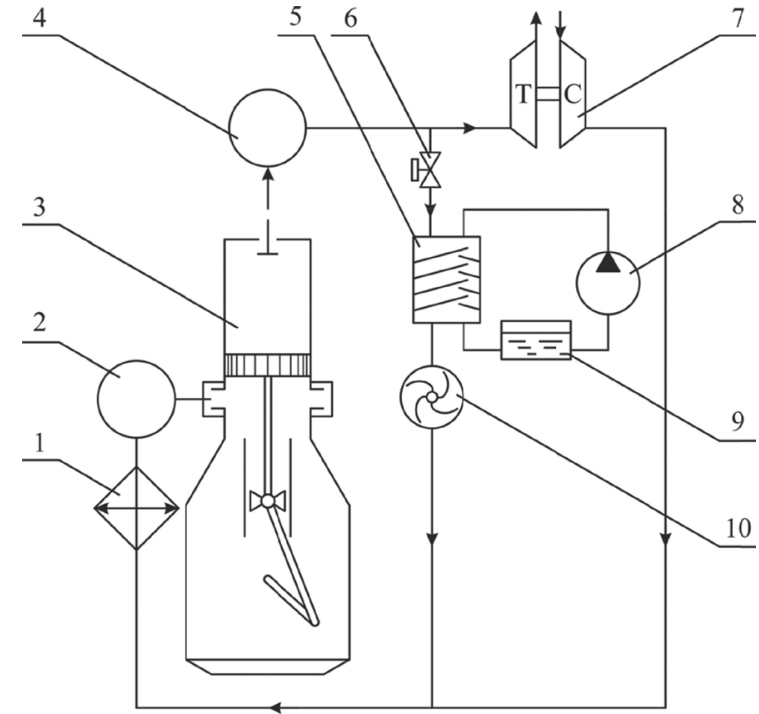

Figure 5 Schematic Diagram of the Exhaust Gas Recirculation System for a Low-Speed marine diesel engine:

1 - air cooler; 2 - air receiver; 3 - diesel cylinder; 4 - exhaust manifold; 5 - scrubber; 6 - exhaust gas recirculation control

valve; 7 - gas-turbocharger; 8 - water pump; 9 - water tank; 10 - gas supercharger with an electric gear.

Slika 5. Shematski dijagram sustava za recirkulaciju ispušnih plinova kod sporohodnih dizelskih motora:

1 - hladnjak zraka; 2 - usisni kolektor; 3 - cilindar dizelskog motora; 4 - ispušni razvodnik; 5 - ispirač plinova; 6 - ventil za recirkulaciju ispušnih plinova; 7 - plinski turbopunjač; 8 pumpa za vodu; 9 - spremnik za vodu; 10 - plinski kompresor s električnom opremom

which makes it possible to obtain the mean effective pressure $p_{i}$. Knowing the value of $p_{i}$ (in MPa), as well as the characteristics of the diesel engine and its operation mode, it is possible to calculate the value of $N_{e}$ (in $\mathrm{kW}$ ) by the following expression:

$$
N_{e}=\frac{V_{s} n i m}{60} p_{i} \eta_{m}
$$

where $V_{s}$ - cylinder capacity, $\mathrm{m}^{3}$;

$n$ - rotation frequency, rpm;

$i$ - number of cylinders;

$m$ - coefficient of tacticity (for the considered diesel engine, $m=1)$;

$p_{i}$ - mean effective pressure, $\mathrm{MPa}$;

$\mathrm{h}_{m}$ - mechanical coefficient of the diesel engine, which was $\mathrm{h}_{m}=0,903 \ldots 0,924$ depending on the operation mode of the diesel engine when conducting an experiment in accordance with the instruction manual.

Specific fuel oil consumption (SFOC) was calculated by the expression $\mathrm{SFOC}=b_{e}=\hat{A}_{h} / N_{e}$ where the hourly fuel consumption $\mathrm{Bh}$ was determined by the flow meter installed on the fuel line.

It is most expedient to monitor the concentration of harmful components in exhaust gases with the help of portable gas analyzers (Hibino et al., 1998).

In the course of the experiments, the authors of the research determined the concentration of $\mathrm{NO}_{x}$ (as well as $\mathrm{O}_{2}$ ) with the help of the gas analyzer Testo350XL from Germany. The latter allowed determining the concentration of the following substances: $\mathrm{CO}, \mathrm{O}_{2^{\prime}} \mathrm{N}_{2^{\prime}} \mathrm{NO}_{x^{\prime}} \mathrm{CH}_{4^{\prime}} \mathrm{SO}_{2^{\prime}}$ and $\mathrm{H}_{2} \mathrm{~S}$, as well as the temperature, humidity, speed and differential pressure of the medium. The main characteristics of the Testo350XL are as follows: 
temperature

measurement range $-40 \ldots 1200^{\circ} \mathrm{C}$;

measurement error $\pm 0.5 \%$;

resolution of $0.1^{\circ} \mathrm{C}$;

content of $\mathrm{O}_{2}$ и $\mathrm{N}_{2}$

measuring range $0 \ldots 25$ volumetric \%;

measurement error \pm 1 volumetric \%;

resolution 0.1 volumetric \%;

performance $5 . .20 \mathrm{~s}$;

content of $\mathrm{NO}_{x}$

measurement range $0 . .3000 \mathrm{mln}^{-1}$;

measurement error $\pm 5 \%$ at a measurement range of

$0 . . .2000 \mathrm{mln}^{-1}$;

$\pm 10 \%$ at a measurement range of $2000 \ldots 3000 \mathrm{mln}^{-1}$;

resolution $1 \mathrm{mln}^{-1}$;

performance $1 \ldots 30 \mathrm{~s}$.

The recirculation degree of the exhaust gases was calculated by the following expression:

$$
\delta_{\mathrm{EGR}}=\frac{\alpha_{\mathrm{EGR}}}{\alpha},
$$

where $a$ - the current value of the excess air coefficient depending on the diesel load;

$a_{E G R}$ - excess air coefficient when using the exhaust gas recirculation system.

The excess air coefficient a was calculated by taking into account the volumetric concentrations of $\mathrm{O}_{2, \text { Gas }}$ and $\mathrm{N}_{2, \text { Gas }}$ in exhaust gases (measured with the Testo350XL gas analyzer) by the following expression:

$$
\alpha=\frac{1}{1-3,76 \frac{\mathrm{O}_{2, \mathrm{Gas}}}{\mathrm{N}_{2, \mathrm{Gas}}}},
$$

To recalculate the $\mathrm{NO}_{x, p p m}$ concentration (measured in $\mathrm{mln}^{-1}$ or ppm) measured with the help of the gas analyzer Testo350XL in the required IMO value in $\mathrm{g} /(\mathrm{kW} \times \mathrm{h})$, the mass of the exhaust gases $G_{\text {Gas' }} \mathrm{kg} / \mathrm{h}$, coming out of the diesel engine was calculated:

$$
G_{\mathrm{Gas}}=\alpha L_{0} b_{e} N_{e} \varphi_{\mathrm{a}},
$$

where $L_{0}=0.495 \mathrm{kmol} / \mathrm{kg}$ - theoretically required amount of combustion air;

$\varphi_{\mathrm{a}}$ - blowdown coefficient.

Afterwards, the concentration of $\mathrm{NO}_{\mathrm{x}, \mathrm{kg} / \mathrm{h}}$ was calculated:

$$
\mathrm{NO}_{x, \mathrm{kgh}}=\frac{\mathrm{NO}_{x, \mathrm{ppm}} G_{\mathrm{Gas}}}{\operatorname{limNO_{x}}},
$$

where $\operatorname{limNO} \mathrm{N}_{x}$-the maximum possible value of NOx concentration determined by the Testo350XL gas analyzer $\left(2000^{-1}\right.$ or $3000 \mathrm{mln}^{-1}$ depending on the selected measurement range).

Afterwards, taking into account the value of the effective power of the diesel $\mathrm{Ne}$, the required NOx concentration in the IMO dimension was calculated in the following way:

$$
\mathrm{NO}_{\mathrm{x}}=\frac{\mathrm{NO}_{\mathrm{x}, \mathrm{kg} / \mathrm{h}}}{N_{e}},
$$

\section{RESULTS / Rezultati}

The experiments were performed for the following highspeed diesel operation modes: 55, 65, 75, and $80 \mathrm{rpm}$, which corresponded to the following values of the relative power of the diesel: $0.3 \mathrm{Nenom}, 0.5 \mathrm{Nenom}, 0.77 \mathrm{Nenom}$, and $0.93 \mathrm{Nenom}$ The high-speed mode that corresponded to $80 \mathrm{rpm}$ provided reliable operation of the diesel without overload even upon instantaneous changes in the resistance of the vessel's movement (due to increased wind strength and sea waves). Therefore, the maximum value of the rotational speed of the diesel shaft in experiments was limited to this value. The remaining high-speed operation modes $(55,65$, and $75 \mathrm{rpm})$ were chosen arbitrarily.

During the experiments, the recirculation degree of flue gases varied in the following values: $E G R=4.7 \%$, $E G R=9.8 \%$, $\mathrm{EGR}=14.6 \%$, $\mathrm{EGR}=18.8 \%$, and was determined by the excess air coefficient value in accordance with the previously described technique.

For each operation mode of the diesel, the specific effective fuel consumption was determined with the help of marine measurement methods.

The rated power that corresponded to its excess air coefficient value a was used as $N_{\text {enom. }}$.

The research results are shown in Figure 6-8.

The dynamics of the change in the $\mathrm{NO}_{\mathrm{x}}$ emission in exhaust gases for different engine speeds of the diesel crankshaft and different levels of exhaust gas recirculation is reflected in the diagram in Fig. 6. At the same time, "1" stands for the NOx emission level when the diesel engine is operating without an EGR system, and " 2 " is the same value when using a recirculation system.

Different speeds of diesel operation have their corresponding SFOC values. A change in this parameter can also be caused by an increase or decrease in the EGR degree, which is reflected in the diagram in Figure 7. Here (similarly to Figure 6), position "1" corresponds to the SFOC value when the engine works without an EGR system, and "2" stands for the same value when a recirculation system is used.

Using an EGR system reduces the amount of "clean" air that enters the diesel cylinder, which leads to a reduction in the effective power of the diesel engine [Likhanov \& Lopatin, 2017]. The change in its values for different degrees of recirculation is shown in Fig. 8 (the "0" position corresponds to the operation of the diesel without the use of a recirculation system). The values of the effective power Ne were determined at a rotational speed of the diesel engine's crankshaft of $80 \mathrm{rpm}$ (corresponding to $0.93 N_{\text {enom }}$ ).

\section{DISCUSSION / Rasprava}

The results published in this article are consistent with a number of other scientific studies [Erokhov, 2013; Ruan et al., 2012; Geng et al., 2017].

The forced filling of the diesel cylinder with exhaust gases provided by the EGR recirculation system leads to a decrease in the temperature during the fuel combustion, which helps to reduce the number of nitrogen oxides generated by the thermal mechanism. At the same time, the concentration of NOx in the exhaust gases decreases depending on the increase in the recirculation rate of the EGR system. Similar results are achieved upon an increase in the intensity of the supply of exhaust gases to the cylinder (upon an increase in the EGR rate) [Lee et al., 2010].

An increase in the degree of gas recirculation in the EGR system reduces the effective power of the diesel engine. According to the authors of this research, this is due to the 


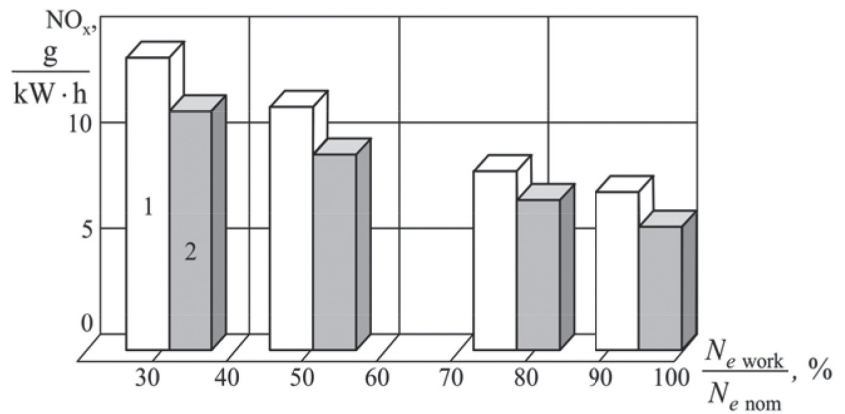

a)

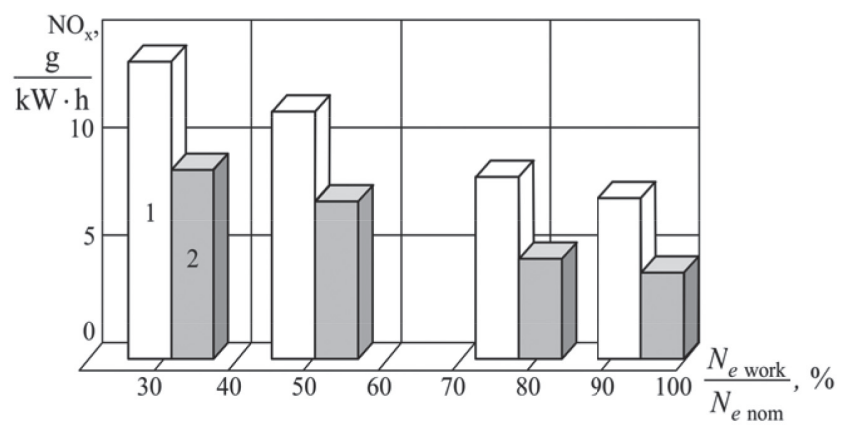

c)

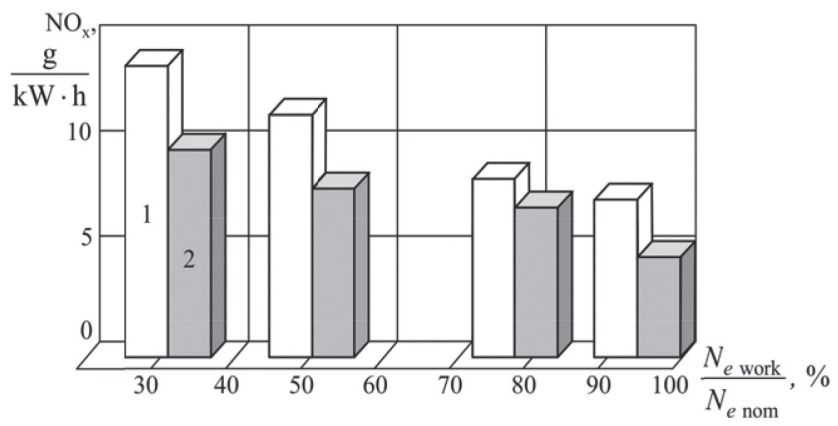

b)

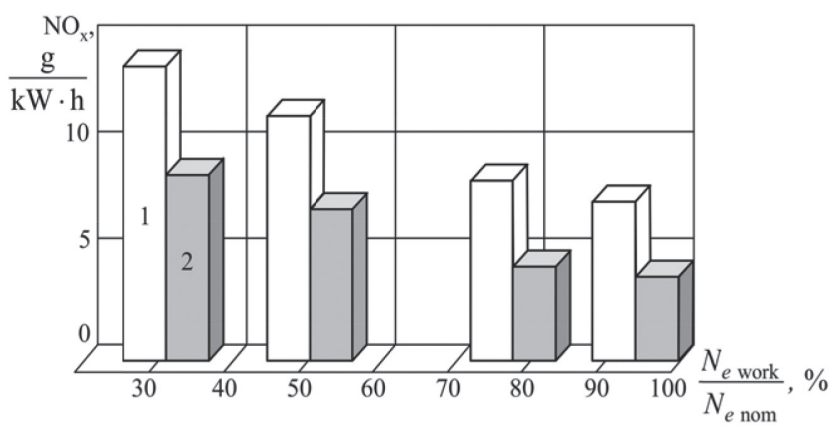

d)

Figure 6 The Change in the NOx Concentration in the Exhaust Gases of the Mitsubishi Diesel Engine 7UEC60LS Depending on the Load for Various Degrees of Recirculation: a) $E G R=4.7 \%$; b) $E G R=9.8 \%$; c) $E G R=14.6 \%$; d) $E G R=18.8 \%$; 1 - operation without recirculation; 2 - operation with recirculation

Slika 6. Promjena koncentracije dušikovih oksida u ispušnim plinovima Mitsubishi dizelskog motora 7UEC60LS ovisno o opterećenju za razne stupnjeve recirkulacije: a) $E G R=4.7 \%$; b) $E G R=9.8 \%$; c) $E G R=14.6 \%$; d) $E G R=18.8 \%$; 1 - rad bez recirkulacije; 2 - rad s recirkulacijom

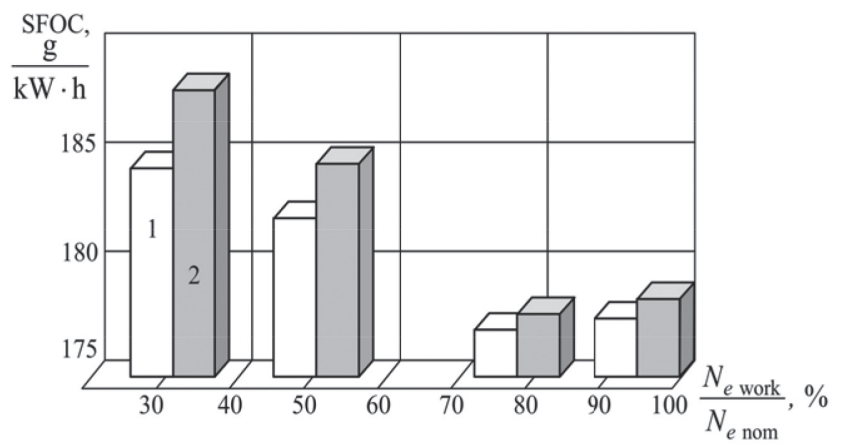

a)

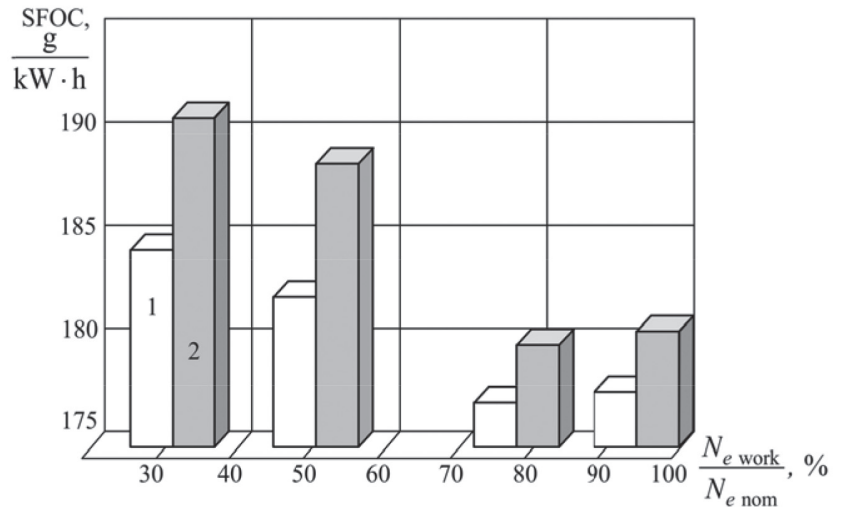

c)

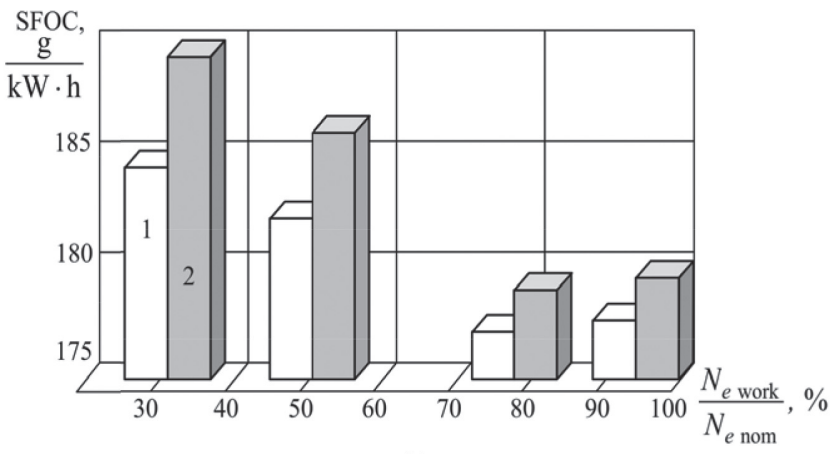

b)

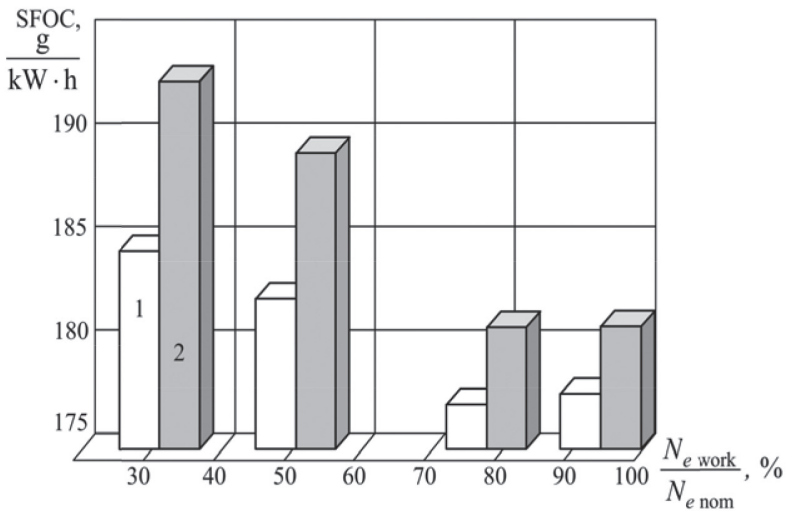

d)

Figure 7 The Change in the Specific Effective Fuel Consumption of the SFOC of the Mitsubishi Marine Diesel Engine 7UEC60LS

Depending on the Load for Various Degrees of Recirculation: a) $E G R=4.7 \%$; b) $E G R=9.8 \%$; c) $E G R=14.6 \%$; d) $E G R=18.8 \%$; 1 - operation without recirculation; 2 - operation with recirculation

Slika 7. Promjena u specifičnoj učinkovitoj potrošnji goriva SFOCa Mitsubishi brodskog dizelskog motora 7UEC60LS ovisno o opterećenju za razne stupnjeve recirkulacije: a) $E G R=4.7 \%$; b) $E G R=9.8 \%$; c) $E G R=14.6 \%$; d) $E G R=18.8 \%$;

1 - rad bez recirkulacije; 2 - rad s recirkulacijom 


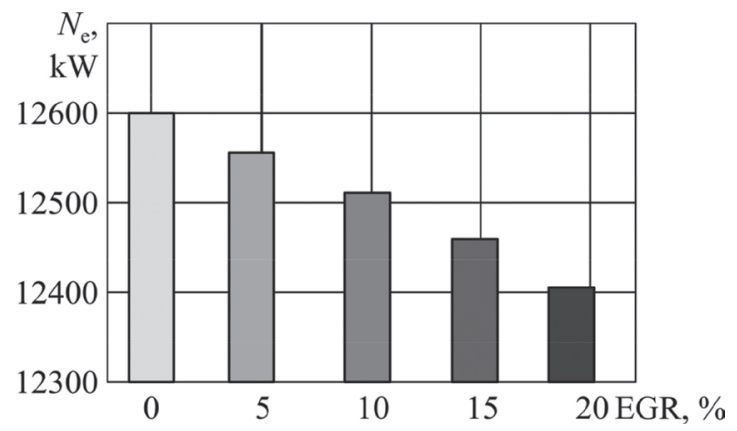

Figure 8 Reduction in the Effective Power of the Diesel Engine for Various Degrees of Exhaust Gas Recirculation for the Operational Load of $0.93 \mathrm{~N}_{\text {enom }}$

Slika 8. Smanjenje efektivne snage dizelskog motora za razne stupnjeve recirkulacije ispušnih plinova za radno opterećenje od $0.93 N_{\text {eno }}$

reduction in the number of exhaust gases that enter the gas turbocharger and the simultaneous proportional increase in the number of exhaust gases that enter the diesel cylinder (through the recirculation system). The former reduces the power of the gas turbocharger NT, while the latter reduces the filling coefficient of the cylinder with fresh air. In both cases, there is a direct-proportional dependence of one parameter on the other, i.e. NT GT and $\mathrm{Ne} \sim \mathrm{hH}$, which causes a drop in the effective power upon increasing the EGR degree.

The decrease in the effective power of using EGR systems in modes that are close to the rated load is Nework $=(0.77 \ldots 0.93)$ Nenom is $0.3 \ldots 1.2 \%$. With a high-quality technical operation of the diesel engine, it does not have a significant effect the speed characteristics of the vessel. When using EGR systems on Nework $=(0.3 \ldots 0.5)$ Nenom loads, the relative reduction in the effective power is $2.4 \ldots 3.4 \%$. Such a significant drop in the power should be explained by the deterioration of gas exchange in the cylinder and the increase in the heat exchange between the air-gas mixture and the cylinder walls at low rotational speeds of the crankshaft.

The increase in the number of exhaust gases entering the diesel cylinder with at an increasing EGR recirculation rate and the deterioration of the gas exchange in the cylinder are the main cause of SFOC growth when using an EGR system. According to the authors of the research, this is caused by a change in the stoichiometric ratio, as well as the increase in the heat loss due to the incompleteness of fuel combustion. The greatest increase in the specific effective fuel consumption corresponds to the diesel engine's operation mode at the minimum engine speed. Similar results were obtained when studying the effect of the EGR system on the work process of a deformed diesel engine [Stein \& Panfilov, 2016].

\section{CONCLUSION / Zaključak}

The use of the research results can contribute to the selection of optimal EGR modes, which will make it possible to meet the requirements of international standards for the environmental characteristics of marine diesel engines (in particular, for $\mathrm{NO}_{x}$ emissions) on the one hand, and to ensure minimum losses of effective diesel power and a minimal increase in SFOC on the other hand. In addition, the choice of optimal operation modes of the ERG system (according to the authors of this research) should help maintain the required technical condition both for the recirculation system itself and the diesel elements (in particular, the cylinder group). In this regard, it is important to find the optimal degree of EGR for each speed mode of the diesel engine. This correspondence can be achieved only experimentally.

Based on the above results, the following conclusions can be made.

A change in the degree of recirculation of exhaust gases in the $4.7 \ldots 18.8 \%$ range ensures a reduction in the NOx concentration of nitrogen oxides in the exhaust gases from 13.5 tо 3.813 .5 до $3.8 \mathrm{gNO}_{\mathrm{x}} /(\mathrm{kW} \times \mathrm{h})$ depending on the diesel load, which varied in the range $(0.3 \ldots 0.93) N_{\text {enom }}$ in the experiments. The decrease in the NOx concentration in the exhaust gases is in the range of $19.5 \ldots 48.8 \%$, with the large values corresponding to $(0.77 \ldots 0.93) N_{\text {enom }}$ range of loads, i.e. the most common operational mode of the diesel engine.

Using the recirculation of exhaust gases to reduce the concentration of $\mathrm{NO}_{x}$ in them degrades the fuel combustion process, which directly affects the parameter of Specific fuel oil consumption. Its value (according to the research) increases proportionally to the increase in the recirculation degree of the exhaust gases. In the percentage ratio, it is 0.85 ... $2.01 \%$ for the case of $\mathrm{EGR}=4.7 \%$, and $2.16 \ldots 4.34 \%$ for the case of $\mathrm{EGR}=$ $18.8 \%$.

At present, the use of recirculation of exhaust gases for reducing the NOx concentration in the exhaust gases of marine diesel engines is the most optimal method, first of all, in terms of its technological execution. The use of the EGR method on marine vessels ensures the fulfilment of international requirements for protecting the ambient air from pollution and can be successfully applied in marine power engineering.

\section{Acknowledgments / Zahvale}

The above research was carried out in accordance with the plan for the implementation of research works at the National University "Odessa Maritime Academy" on the theme "Development of Systems and Methods for Improving the Technical Operation of Marine Power Plants Based on Modern Information Technology."

The authors of the research express their gratitude to the scientific vice-principal of the National University "Odessa Maritime Academy", Doctor of Technical Sciences and Professor Golikov Vladimir Antonovich for helping to develop a plan and methodology for the research, as well as for his recommendations on the organization of experimental technology and the summarization of the research results.

\section{REFERENCES / Literatura}

[1] Ajayi, O. O., Fenske, G. R., Goldblatt, I. L., Aldajah, S. (2007) Effect of exhaust gas recirculation (EGR) contamination of diesel engine oil on wear. Wear 263(1-6): 9398. DOI: 10.1016/j.wear.2006.12.055. https://doi.org/10.1016/j.wear.2006.12.055

[2] Balzani, J. M., Alfoldy, B., Hjorth, J. (2014) Field test of available methods to measure remotely SOX and NOX emissions from ships. Atmospheric measurement techniques 7(8): 2597-2613. DOI: 10.5194/amt-7-2597-2014. https://doi.org/10.5194/amt-7-2597-2014

[3] Belousov, E.V., Ageev, M.S., Sviridov, V.I. (2010) Vliyanie na rabochiy protsess sredneoborotnogo sudovogo dizelya putem vpryskivaniya vody $\mathrm{v}$ rabochiy tsilindr [Influencing the Working Process of Medium-Speed Ship Diesel by Injecting Water into the Working Cylinder]. Dvigateli vnutrennego sgoraniya [Internal Combustion Engines] 1: 40-43.

[4] ErokhovV.I. (2013) Sistema retsirkulyatsii otrabotavshikh gazov sovremennykh dvigateley. Exhaust Gas Recirculation System for Modern Engines. Transport na altermativnom toplive [Vehicles Working by Alternative Fuels] 4(34): 36-42. 
[5] Geng, P., Wei, L., You, K., Ju, J., Chen, T., Mao, H., Zhang, Y. (2017) Combustion characteristics and NOx emissions of a waste cooking oil biodiesel blend in a marine auxiliary diesel engine. Applied Thermal Engineering 115: 947954. DOI: 10.1016/j.applthermaleng.2016.12.113. https://doi.org/10.1016/j. applthermaleng.2016.12.113

[6] Gureev, V. M., Khairullin, A. K., Varlamov, F. A., Gumerov, I. F., Khafizov, R. K. (2016) Influence of exhaust gas recirculation on technical, economic, and environmental performance of high-uprated diesel aircraft engine. Russian Aeronautics 59(4): 554-558. DOI: 10.3103/S1068799816040188.

[7] Gusakov, S. V., Vallejo Maldonado, P. R., Dovolnov, A. M. (2008) Vliyanie nizkoi vysokotemperaturnoy retsirkulyatsii otrabotavshikh gazov na rabochiy protsess dvigatelya vnutrennego sgoraniya [The Influence of Low- and HighTemperature Exhaust Gas Recirculation on the Working Process of an Interna Combustion Engine]. Vestnik RUND, seriya Inzhenernye issledovaniya [Vestnik of RUND, Engineering Studies] 2: 80-84.

[8] Hibino, T., Kuwahara, Y., Otsuka, T., Ishida, N., Oshima, T. (1998) NOX detection using the electrolysis of water vapour in an YZL cell - Part I. NOX detection. Solid State lonics 107 (3-4): 213-216. https://doi.org/10.1016/S01672738(97)00538-9

[9] Hodjati, S., Vaezzadeh, K., Petit, C., Pitchon, V., Kiennemann, A. (2000) NOX sorption-desorption study: application to diesel and lean-burn exhaust gas (selective NOX recirculation technique). Catalysis Today 59(3-4): 323334. DOI: 10.1016/S0920-5861(00)00298-4. https://doi.org/10.1016/S0920 5861(00)00298-4

[10] Koci, P., Plat, F., Stepanek, J., Kubicek, M., Marek, M. (2008) Dynamics and selectivity of NOX reduction in NOX storage catalytic monolith. Catalysis Today 137(2-4): 253-260. DOI: 10.1016/j.cattod.2007.11.023. https://doi. org/10.1016/j.cattod.2007.11.023

[11] Kotman, P., Bitzer, M., Kugi, A. (2010) Flatness-based feedforward control of a two-stage turbocharged diesel air system with EGR. 2010 IEEE International conference on control application, CCA 2010. Yokohama, September, 0810: 979-984. DOI: 10.1109/CCA.2010.5611065. https://doi.org/10.1109/ CCA.2010.5611065

[12] Kumar Rajesh, B., Saravanan S. (2016) Partially premixed low-temperature combustion using dimethyl carbonate (DMC) in a DI diesel engine for favourable smoke/NOx emissions. Fuel 180(15): 396-406. DOI: 10.1016/j. fuel.2016.04.060. https://doi.org/10.1016/j.fuel.2016.04.060

[13] Lee, H., Sunwoo, M., Lee, J. (2014) Fault Diagnosis of Exhaust Gas Recirculation and Variable Geometry Turbocharger Systems in a Passenger Car Diesel Engine Based on a Sliding Mode Observer for Air System States Estimation. Journa of Dynamic Systems, Measurement and Control, Transactions of the ASME 136(3): 3-16. DOI: 10.1115/1.4026131. https://doi.org/10.1115/1.4026131

[14] Lee, K., Kim, T., Cha, H., Song, S., Chun, K. M. (2010) Generating efficiency and NOX emissions of a gas engine generator fueled with a biogas-hydrogen blend and using an exhaust gas recirculation system. International Journa of Hydrogen Energy 35(11): 5723-5730. DOI: 10.1016/j.ijhydene.2010.03.076. https://doi.org/10.1016/j.ijhydene.2010.03.076

[15] Li, T., Susuki, M., Ogawa, H. (2010) Effect of two-stage injection on unburned hydrocarbon and carbon monoxide emissions from ultra-high EGR lowtemperature diesel combustion. Nippon Kikai Gakkai Ronbunshu 766(76): 1004-1009.

[16] Likhanov, V. A., Lopatin, O. P. (2017) Rabochiy protsess dizelya na prirodnom gaze s retsirkulyatsiey [The Working Process of a Diesel Engine by Natural Gas with Recirculation].Vestnik transporta Povolzhiya [Newsletter of Transport of the Volga Region] 2(62): 105-112.

[17] Manieniyan, V., Vinodhini, G., Senthilkumar, R., Sivapkarasam, S. (2016) Wear element analysis using neural networks of a DI diesel engine using biodiese with exhaust gas recirculation. Energy 114(1): 603-612. DOI: 10.1016/j. energy.2016.08.040. https://doi.org/10.1016/j.energy.2016.08.040

[18] Miller Jothi, N. K., Nagarajan, G., Renganarayanan, S. (2008) LPG fueled diese engine using diethyl ether with exhaust gas recirculation. International Journal of Thermal Sciences 47(4): 450-457. DOI: 10.1016/j.ijthermalsci.2006.06.012. https://doi.org/10.1016/j.ijthermalsci.2006.06.012
[19] Nova, I., Lietti, L., Forzatti, P. (2008) Mechanistic aspects of the reduction of stored NOx over Pt-Ba/Al2O3 lean NOX trap systems. Catalysis Today 136(12): 128-135. DOI: 10.1016/j.cattod.2008.01.006. https://doi.org/10.1016/j. cattod.2008.01.006

[20] Petzold, A, Lauer, P, Fritsche, U Hasselbach, J, Lichtenstern, M, Schlager, H., Fleischer F. (2011) Operation of Marine Diesel Engines on Biogenic Fuels: Modification of Emissions and Resulting Climate Effects. Environmental Science \& Technology 45(24): 10394-10400. DOI: 10.1021/es2021439. https:// doi.org/10.1021/es2021439

[21] Rakhmatov, R.I. (2014) Tendentsii razvitiya system obrabotki gazov dlya diselnogo dvigatelya [Trends in the Development of Gas Treatment Systems for a Diesel Engine]. Sovremennye problemy teorii mashin [Modern Problems of the Theory of Machines] 2: 141-145.

[22] Ruan, G., Zhang, Z., Wang, O. (2012) Exhaust gas recirculation control based on artificial neural network. International Journal of Advancements in Computing Technology 4(19): 131-138. DOI: 10.4156/ijact.vol4.issue 19.17

[23] Sagin, S. V., Semenov, O. V. (2016) Motor Oil Viscosity Stratification in Friction Units of Marine Diesel Motors. American Journal of Applied Sciences 13(2): 200-208. DOI: 10.3844/ajassp.2016.200.208. https://doi.org/10.3844/ ajassp.2016.200.208

[24] Sagin, S. V., Solodovnikov, V. G. (2015) Cavitation Treatment of High-Viscosity Marine Fuels for Medium-Speed Diesel Engines. Modern Applied Science 9(5): 269-278. DOI:10.5539/mas.v9n5p269. https://doi.org/10.5539/mas. v9n5p269

[25] Stein, G. V., Soklakov, S. A. (2015) Vliyanie rezhima raboty systemy "EGR" na toplivno-ekologicheskie pokazateli avtomobilnogo dvigatelya [The Influence of the Operational Mode of the "EGR" System on the Fuel and Environmental Parameters of an Automobile Engine]. Sbornik materialov mezhdunarodnoy nauchno-practicheskoy konferentsii "Problemy funktsionirovaniya sistem transporta" [Proceedings of the International Scientific and Practical Conference "Problems of the Functioning of Transport Systems"], December 14-15, 2015, Tyumen, Tyumen State Oil and Gas University, 254-257.

[26] Stein, G.V Panfilov, A.A. (2016) K voprosu o protivorechiyakh mezhdu ekologicheskimi i toplivno-ekonomicheskimi pokazatelyami dizelnogo topliva [On the Problem of the Contradictions between Environmental and Fuel-Economic Indicators of a Diesel Engine]. Nauchnoe Obozrenie [Scientific Review] 18: 66-70.

[27] Vanin, V. K., Shcheglov, P. A. (2014) Problemy zagryazneniya teploobmennikov okhlazhdeniya retsirkuliruyushchikh gazov i puti ee resheniya [Problem of Pollution of Heat Exchangers for Cooling of Recirculating Gases and Ways of Solution]. Trudy NAMI [Scientific works of Nauchno-Avtomotorny Institute (NAMI)] 258: 177-185.

[28] Xu, F., Wang, Z., Yang, D. B., Wang, J. X. (2010) External EGR combined with EGR for high load extension on a gasoline $\mathrm{HCCl}$ engine. Neiranji Gongcheng 31(4): 6-10.

[29] Yoo, J., Prikhodko, V., Parks, J.E., Partridge, W.P., Perfetto, A., Geckler, S. (2016) High-speed multiplexed spatiotemporally resolved measurements of exhaust gas recirculation dynamics in a multi-cylinder engine using laser absorption spectroscopy. Applied Spectroscopy 70(4): 572-584. DOI: 10.1177/0003702816636802. https://doi.org/10.1177/0003702816636802

[30] Zablotsky, Yu. V., Sagin, S. V. (2016) Maintaining Boundary and Hydrodynamic Lubrication Modes in Operating High-pressure Fuel Injection Pumps of Marine Diesel Engines. Indian Journal of Science and Technology 9(20): 208-216. DOI: 10.17485/ijst/2016/v9i20/94490. https://doi.org/10.17485/ ijst/2016/v9i20/94490

[31] Zhao, Y., Li, M., Xu, G., Chen, Q., Wang, Z. (2016) Effect of EGR exhaust gas component on oxidation activity of particle from diesel engine. Nongye Congcheng Xuebao 32(23): 58-63. DOI: 10.11975/j.issn.10026819.2016.23.008.

[32] Zheng, M., Asad, U., Reader, G.T., Tan, Y., Wang, M. (2009) Energy efficiency improvement strategies for a diesel engine in low-temperature combustion. International Journal of Energy Research 33(1): 8-28. DOI: 10.1002/er.1464. https://doi.org/10.1002/er.1464 